\title{
New Roles of Serotonin and Tachykinins in Intestinal Mucositis?
}

\author{
Brid Callaghan $\cdot$ John B. Furness
}

Published online: 26 October 2013

(C) Springer Science+Business Media New York 2013

The paper by Matsumoto et al. [1] published in this issue of Digestive Diseases and Sciences reports an investigation of expression of 5-hydroxytrypamine (5HT) and tachykinins and their cognate receptors in an experimental model of mucositis of the mouse jejunum induced by the chemotherapeutic agent 5-fluorouracil (5-FU).

Mucositis is a serious adverse effect of common chemotherapeutic treatments. Damage to mucosa, prominent in the oral cavity (oral mucositis), also occurs in the esophagus, stomach, and small and large intestines (gastrointestinal mucositis). Gastrointestinal symptoms include pain, nausea and vomiting, ulceration, diarrhea, and rectal bleeding. Patients with mucositis often have to temporarily withdraw from chemotherapy, which can contribute to reduced cancer survival [2]. Current guidelines for treatment of gastrointestinal mucositis include use of the oral histamine $\mathrm{H}_{2}$-receptor antagonist ranitidine or a proton pump inhibitor to reduce gastric injury. Loperamide is recommended for control of diarrhea; if loperamide fails, subcutaneous octreotide is also recommended [3]. Mucosal damage was originally believed to result primarily from inhibition of epithelial cell proliferation, which reduces protection and repair of the mucosa. More recent evidence shows that chemotherapeutic agents stimulate nuclear factor- $\kappa \mathrm{B}$ production; subsequent production of proinflammatory cytokines significantly induces mucositis [4].

B. Callaghan · J. B. Furness $(\square)$

Department of Anatomy and Neuroscience, University of Melbourne, Parkville, VIC, Australia

e-mail: j.furness@unimelb.edu.au

B. Callaghan

e-mail: b.callaghan@unimelb.edu.au
Therapy limiting intestinal mucosal damage is not in common use, primarily because suitable molecular targets have not been identified.

The publication by Matsumoto et al. builds on their previous findings that $5 \mathrm{HT}_{3}$ receptor antagonists reduce damage to mucosa, mucosal cytokine production, and enterocyte apoptosis caused by 5-FU in mice [5]. Their latest paper reports that $5 \mathrm{HT}_{3}$ and neurokinin $(\mathrm{NK}) \mathrm{NK}_{1}$ receptor expression were upregulated, mostly in lamina propria macrophage-like cells (CD11+) of the jejunum, of mice injected intraperitoneally with 5 -FU for 5 days, investigated on the 5th day. The study also reports increased 5HT and tachykinin (substance P) content of small intestine homogenate, although the number of cells expressing these compounds was unchanged. The number of mucosal $5 \mathrm{HT}_{3}$ receptor immunoreactive nerve fibers also increased.

An important unanswered question is whether the results are clinically relevant, given that numerous studies have reported that $5 \mathrm{HT}_{3}$ receptors help modulate the immuneinflammatory axis. Rodents have only two genes encoding $5 \mathrm{HT}_{3}$ subunits whereas the human genome contains five $5-\mathrm{HT}_{3}$ receptor-encoding genes, although the $5 \mathrm{HT}_{3 \mathrm{C}}$, $5 \mathrm{HT}_{3 \mathrm{D}}$, and $5 \mathrm{HT}_{3 \mathrm{E}}$ subunits only express functional channels when co-expressed with $5 \mathrm{HT}_{3 \mathrm{~A}}$ [6]. It is currently unclear whether any of the $5 \mathrm{HT}_{3}$ receptor subtypes are expressed on human macrophages. $5 \mathrm{HT}_{2 \mathrm{~B}}$ and $5 \mathrm{HT}_{7}$ were the only serotonin receptor-encoding genes expressed above background levels in human macrophages produced by treatment of peripheral monocytes with GM-CSF or M-CSF (granulocyte macrophage and macrophage colonystimulating factors) [7]. Kapellar et al. [6] detected immunoreactivity to $5 \mathrm{HT}_{3 \mathrm{~A}}, 5 \mathrm{HT}_{3 \mathrm{C}}, 5 \mathrm{HT}_{3 \mathrm{D}}$, and $5 \mathrm{HT}_{3 \mathrm{E}}$ in lamina propria immune cells in the human colon, although their identity was not verified. There is, however, good evidence that $5 \mathrm{HT}_{3}$ receptors are expressed on human 
monocytes, T cells, and mast cells, if not on macrophages themselves [8].

The importance of the results is that $5 \mathrm{HT}_{3}$ receptor antagonists, effective in reducing chemotherapy-induced nausea by blocking emetogenic pathways [9], may have additional mucosa-protective effects. Combined with results published previously by this group, the observations imply that activation of $5 \mathrm{HT}_{3}$ receptors on macrophages releases cytokines that contribute to the mucosal damage of mucositis. Further evidence in support of this theory might be obtained from experiments utilizing macrophage-deficient mice.

$\mathrm{NK}_{1}$ receptor antagonists protect against tachykininmediated hypersecretion and inflammatory responses in animal models of ileocolitis [10]. The functional relevance of increased macrophage $\mathrm{NK}_{1}$ receptor expression in mucositis should be investigated, because $\mathrm{NK}_{1}$ receptor antagonists, for example aprepitant, are in use as antinauseants and might augment the anti-nausea and potential mucosa-protective activity of $5 \mathrm{HT}_{3}$ receptor antagonists, for example granisetron and odansetron.

In summary, current options for treatment of, or prevention of the development of, chemotherapy-induced gastrointestinal mucositis are limited. $5 \mathrm{HT}_{3}$ receptor antagonists and a $\mathrm{NK}_{1}$ receptor antagonist are already used clinically, alone or in combination, to reduce chemotherapy-induced nausea and are attractive options for reducing damage to mucosa. $5 \mathrm{HT}_{3}$ receptor antagonists, by reducing 5HT-induced cytokine production, may limit the contributions of pro-inflammatory cytokines to mucositis. Nevertheless, the effectiveness of $5 \mathrm{HT}_{3}$ and $\mathrm{NK}_{1}$ receptor antagonists in mucosa protection in human mucositis, as opposed to a mouse model, remains to be proved.

\section{References}

1. Matsumoto K, Nakajima T, Sakai $\mathrm{H}$ et al. Increased expression of $5-\mathrm{HT}_{3}$ and $\mathrm{NK}_{1}$ receptors in 5-fluorouracil induced mucositis in mouse jejunum. Dig Dis Sci. (Epub ahead of print) doi: 10.1007/ s10620-013-2709-7.

2. Thorpe D, Stringer A, Butler R. Chemotherapy-induced mucositis: the role of mucin secretion and regulation, and the enteric nervous system. NeuroToxicology. 2013;38:101-105.

3. Peterson DE, Bensadoun R-J, Roila F. Management of oral and gastrointestinal mucositis: ESMO clinical practice guidelines. Ann Oncol. 2011;22:vi78-vi84.

4. Logan RM, Stringer AM, Bowen JM, et al. The role of proinflammatory cytokines in cancer treatment-induced alimentary tract mucositis: pathobiology, animal models and cytotoxic drugs. Cancer Treat Rev.. 2007;33:448-460.

5. Yasuda M, Kato S, Yamanaka N, et al. 5-HT3 receptor antagonists ameliorate 5-fluorouracilinduced intestinal mucositis by suppression of apoptosis in murine intestinal crypt cells. $\mathrm{Br} \mathrm{J}$ Pharmacol. 2013;168:1388-1400.

6. Kapeller J, Möller D, Lasitschka F, et al. Serotonin receptor diversity in the human colon: expression of serotonin type 3 receptor subunits 5-HT3C, 5-HT3D, and 5-HT3E. J Comp Neurol. 2011;519:420-432.

7. de las Casas-Engel M, Domínguez-Soto A, Sierra-Filardi E et al. Serotonin skews human macrophage polarization through $\mathrm{HTR}_{2 \mathrm{~B}}$ and $\mathrm{HTR}_{7}$. J. Immunol. 2013;190:2301-2310.

8. Fiebich BL, Akundi RS, Seidel M, et al. Expression of 5-HT3A receptors in cells of the immune system. Scand J Rheumatol. 2004;33:9-11.

9. Sanger GJ, Andrews PLR. Treatment of nausea and vomiting: gaps in our knowledge Autonom. Neurosci.. 2006;129:3-16.

10. Patacchini R, Maggi CA. Peripheral tachykinin receptors as targets for new drugs. Eur J Pharmacol. 2001;429:13-21. 